\title{
Research ethics - an evolving discipline
}

We are repeating this Editorial which appeared in the November 1999 issue of the Journal and should have accompanied the Research Ethics Guidelines which were omitted.

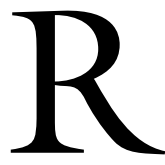

ECOMMENDATIONS for the conduct of medical research were stimulated by the revulsion of experiments performed by the Nazis during the $2^{\text {nd }}$ World War. The Nuremberg code (1947) (www.med.umich.edu/ irmed/ethics/Nuremberg) emphasized that voluntary consent by the subject was essential, experiments should "yield fruitful results for the good of society" and "the degree of risk...should never exceed that determined by the humanitarian importance of the problem to be solved". It might seem extraordinary that it was necessary to include clauses such as "the scientist...must be prepared to terminate the experiment..if he has probable cause to believe....that a continuation...is likely to result in injury, disability, or death of the subject."

The Nuremberg Code was succeeded by the World Medical Association Declaration of Helsinki recommendations (www.umich.edu/irmed/ethics/Helsinki) guiding physicians in biomedical research involving human subjects. They were first adopted in 1964 and amended in $1975,1983,1989$ and 1996. The Declaration of Helsinki states 12 Basic Principles including the assessment of the experimental protocol by an independent committee, a careful assessment of risks, freely-given informed consent, warning to the physician concerning dependent relationships with the subject, and that the research protocol should contain a statement that the principles enunciated in the Declaration are complied with. The Declaration of Helsinki divided research into Medical Research Combined with Clinical Care (Clinical Research) and Non-Therapeutic Biomedical Research involving Human Subjects (Non-Clinical Biomedical Research). Further, the Declaration states that Clinical Research can be combined with clinical care, subject to certain strictures, only to the extent that the research "is jus- tified by its potential diagnostic or therapeutic value for the patient". Conversely, the Declaration states that subjects of Non-Therapeutic research should be volunteers. Subjects of biomedical investigation have been well served by the principles stated so clearly in The Helsinki Declaration wherever it has been applied around the world. However, several aspects of the Declaration are undergoing severe criticism, particularly those related to the separation of Clinical from Non-therapeutic research and the use of placebo therapy in control groups.

In Canada, the Tri-Council Policy Statement: Ethical Conduct for Research Involving Humans ${ }^{1}$ was published in August, 1998 and is available on the Medical Research Council (MRC) web-site (www.mrc.gc.ca). The statement describes the joint policy, towards the conduct of research in humans, of the three councils that are funded to promote, assist and undertake research in Canada [MRC; the Natural Sciences and Engineering Council (NSERC), and the Social Sciences and Humanities Research Council (SSHRC)]. The document is unique in bringing together all those who promote research, not only medical research, in Canada. Its perspective is broadened by reflecting the principles of the modern historian, political scientist and medical researcher. The document is a sensitive, intelligent and thoughtful reflection of many years of widespread discussion in the academic community. It recognizes the special concerns of particular groups, such as Aboriginal Peoples, and is aware that in certain areas such as genetic research, contentious ethical issues remain. The Policy does not offer definitive answers to such questions. Rather, it outlines general ethical principles and identifies major issues for continuing debate to establish consensus. The Policy deserves to be read carefully by all involved in human research, both medical and social scientists. It provides a realistic view of current attitudes, states principles that must be applied and discusses and explains those principles.

Several areas in the Tri-Council Statement are important to anesthesiologists. For example, the composition of the local Research Ethics Board (REB) 
should include at least five individuals of which at least two should have broad experience of the methodology in the area concerned, at least one should be knowledgeable in Ethics, at least one be knowledgeable in the relevant law and at least one should have no affiliation with the establishment but be recruited from the community served by the institution. The Policy is firm in stating that the REB be established by the highest levels of the Institution and cover as broad a range of research as is manageable. Departmental REBs are unacceptable and a multiplicity of REBs with small workloads should be avoided. Throughout the Policy Statement the proportionate approach is emphasized, based on the general principle that the more invasive the research, the greater should be the care in assessing the research.

The requirement for free and informed consent is thoroughly presented with particular emphasis on assessment of harm, full discussion and explanation, protection of incompetent and dependent subjects, and the separate roles of researcher and therapist. The Policy recognizes that in certain emergency health situations REBs may allow research if it addresses the emergency needs of individuals involved.

The Tri-Council Statement also addresses the issue of inclusion of subjects into research protocols. On the basis of the principle of distributive justice, members of society should neither bear an unfair share of the direct burdens of participating in research, nor should they be unfairly excluded from the potential benefits. Unfortunately, biomedical research has tended to exclude the very young and the very old, the incompetent and women of child-bearing age often due to concern with legal liability. Researchers have a duty not to discriminate against disadvantaged groups and this includes women, people of colour or different ethnicity, the elderly, children and dependent people.

With regard to Clinical Trials, the Policy introduces the principle of Clinical Equipoise. This means that at the start of the study there must be uncertainty about the comparative therapeutic merits of each arm of the study so that the health care of subjects is not disadvantaged by research participation. This is of particular relevance in the use of placebo controls which should only be used if there is no standard treatment, if the standard therapy is no better than placebo, if effective treatment is not normally available to patients, or if patients have provided informed refusal of standard therapy for a minor condition for which patients commonly refuse therapy.

The sections discussing Human Genetic Research illustrate the current problems and ethical dilemmas and are relevant to the anesthesiologist who is involved as part of a team in obtaining human tissues. Although the research is exciting, recently acquired knowledge regarding genes and their mutations is not matched with a full understanding of their implications. Consequently, issues related to privacy, confidentiality and genetic counseling predominate. The Policy states unequivocally that it is not ethical to: use ova/sperm obtained through commercial transactions: create hybrid individuals by such means as mixing human and animal gametes: or to create human embryos specifically for research purposes. Much of the recommendations in this section is based on the Royal Commission on New Reproductive Technologies. ${ }^{2}$ Political intrusion on ethical principles is evident by a statement of a former Minister of Health that he would not approve federal funding for procedures that involved the transplantation of tissue obtained from elective abortions even though the Royal Commission recommended that "Research projects using fetal tissue be eligible for funding by the MRC".

The "Guidelines on the Ethics of Clinical Research in Anesthesia", prepared by the Committee of Bioethics of the Canadian Anesthesiologists' Society (CAS) and published in this issue of the Canadian Journal of Anesthesia ${ }^{3}$ amplifies areas of the TriCouncil Statement directly relevant to anesthesia. In particular, the committee recognizes that obtaining informed consent for anesthesia research may be problematic for anesthesia investigators as their first contact with patients may not occur until they are in hospital, often on the same day as their surgical procedure. The Committee states clearly that pre-operative consent for clinical research in anesthesia may be obtained after admission to hospital provided that certain criteria are met: patients are not under the influence of sedative drugs; the risks to the patient are not different from routine clinical care (Clinical Equipoise); and that sufficient time is available for discussion and explanation. The CAS Guidelines recognize and give advice concerning the use of placebos in anesthesia research and emphasize issues relating to privacy and confidentiality, the potential for risks and benefits, vulnerable populations and the declaration of possible conflicts of interest. Together with the Tri-Council Policy Statement, the responsibilities and activities of the anesthesia investigator have been identified. The Guidelines will make it easier to ensure appropriate moral and ethical behaviour on the part of investigators who conduct clinical research with human subjects in Canada.

It is clear that several ethical issues related to biomedical research have not been resolved. At the April 1999 meeting of the World Medical Association, several revisions to the Declaration of Helsinki were proposed. The recommended revisions included waiving 
of the need for written informed consent when the risks posed by the research were slight; that it is desirable rather than mandatory that the consent is obtained by a physician with no conflict of interest; that control groups may be provided with local standard of care rather than the best proven therapy; that placebos may be justified by a scientifically and ethically sound protocol; and that prohibition against publishing unethical research is diluted. Some of the issues leading to the revisions followed studies in the developing world of zidovudine in pregnant women to prevent transmission of HIV to their offspring in which placebo therapy was used in the control subjects rather than the "best proven therapy". The topic has been debated vigorously ${ }^{4,5}$ and demonstrates the need for on-going debate in this contentious area. Nevertheless, the recommendations that have been made by generations of medical investigators have ensured that, in biomedical research, the cardinal principle of respect for human dignity is maintained and that the horrors of the past will never be repeated. In particular, the TriCouncil Policy Statement and the CAS Guidelines have set the rules for the anesthesia community.

\section{L'éthique de la recherche, une discipline qui évolue}

La formulation d'un code d'éthique en recherche médicale a été recommandée à la suite des expériences révulsives réalisées par les Nazis pendant la Seconde Guerre mondiale. Le code de Nuremberg (1947) (www.med.umich.edu/irmed/ethics/Nuremberg) soulignait que le consentement volontaire du sujet était essentiel, que les expériences devaient «être utiles pour le bien de la société» et que «le degré de risque... ne devrait jamais dépasser celui de l'importance humanitaire du problème à résoudre.» Il peut sembler incroyable d'avoir à inclure que «le scientifique... doit se préparer à stopper l'expérimentation...s'il a des raisons de croire...que de la poursuivre...peut provoquer un traumatisme, une incapacité ou la mort du sujet.»

Le Code de Nuremberg a été suivi par les recommandations de la Déclaration d'Helsinki de l'Association médicale mondiale (www.umich.edu/ irmed/ethics/Helsinki) qui servent de guide aux médecins en recherche biomédicale avec des sujets humains. Adoptées en 1964, ces recommandations ont été amendées en 1975, 1983, 1989 et 1996. La Déclaration d'Helsinki établit 12 principes de base, y compris l'évaluation du protocole expérimental par un comité indépendant, l'évaluation attentive des risques, le consentement libre et éclairé, la mise en garde au médecin à propos de relation avec le sujet et l'avis contenu dans le protocole de recherche confirmant que les principes énoncés par la Déclaration y sont respectés. La Déclaration d'Helsinki marquait une division entre la Recherche médicale combinée aux soins cliniques (Recherche clinique) et la Recherche biomédicale non thérapeutique impliquant des sujets humains (Recherche biomédicale non clinique). De plus, la Déclaration établit que la Recherche clinique peut être combinée aux soins cliniques, sous certaines réserves, seulement si l'extension de la recherche «se justifie par sa valeur diagnostique et thérapeutique potentielle pour le patient». Réciproquement, la Déclaration stipule que les sujets qui participent à des recherches non thérapeutiques doivent êtres des volontaires. Les sujets d'investigation biomédicale ont été bien reconnus par les principes énoncés aussi clairement dans la Déclaration d'Helsinki, où qu'ils aient été appliqués dans le monde. Cependant, certains aspects de la Déclaration ont été sévèrement critiqués, surtout ceux qui ont trait à la séparation entre la recherche clinique et la recherche non thérapeutique et à l'usage de placebo chez les sujets témoins.

Au Canada, l'Énoncé de politique des trois Conseils : Éthique de la recherche avec des êtres humains ${ }^{1}$ a été publié en août 1998 et on peut l'obtenir sur le site Internet du Conseil de recherches médicales du Canada (www.mrc.gc.ca). Le mémoire décrit la position commune, concernant la recherche avec des sujets humains, des trois conseils mis sur pied pour promouvoir, faciliter et entreprendre des recherches au Canada [CRM; le Conseil de recherches en sciences naturelles et en génie du Canada (CRSNG) et le Conseil de recherches en sciences humaines du Canada (CRSH)]. C'est un document unique qui rassemble tous ceux qui font la promotion de la recherche, non seulement médicale, au Canada. Sa perspective élargie reflète les principes de l'histoire moderne, de la science politique et de la recherche médicale. Le document se veut une réflexion sensible, intelligente et profonde de nombreuses années d'importantes discussions dans la communauté universitaire. Il reconnaît les préoccupations de groupes particuliers, comme les peuples autochtones, et rappelle que dans certains domaines, comme la recherche en génétique, des questions d'éthique soulèvent encore la controverse. L'énoncé ne présente pas de réponses définitives à ces questions. Il ébauche plutôt des 
principes éthiques généraux et identifie des sujets importants dont il faut continuer de débattre en vue d'un accord. L'énoncé mérite d'être lu attentivement par tous ceux qui font de la recherche avec des humains, autant en sciences médicales que sociales. Il fournit une vision réaliste des idées actuelles, présente, explique et établit les principes qui devront s'appliquer.

Certaines parties de l'Énoncé des trois Conseils sont importantes pour les anesthésiologistes. Ainsi, la composition du comité local d'éthique de la recherche (CER) doit comprendre au moins cinq personnes dont au moins deux connaissent parfaitement la méthodologie des disciplines concernées, au moins une est versée en éthique, au moins une a des connaissances juridiques appropriées aux projets et au moins une provient de la collectivité desservie par l'établissement mais n'y est pas affiliée. L'énoncé déclare avec fermeté que le CER doit être créé par les plus hautes autorités institutionnelles, couvrir un éventail de recherches, gérable, aussi large que possible. Les CER départementaux ne sont pas acceptables et une multiplicité de CER de faibles charges de travail sont à éviter. L'énoncé de politique met l'accent sur la méthode proportionnelle basée sur le principe général que plus la recherche risque d'être effractive, plus elle doit être soigneusement évaluée.

La nécessité du consentement libre et éclairé y est présentée avec une insistance particulière sur l'évaluation des effets nuisibles, la présentation et l'explication complètes du projet, la protection des sujets inaptes et dépendants et les rôles distincts de chercheur et de thérapeute. L'énoncé reconnaît que dans certaines situations d'urgence les CER peuvent permettre la recherche si celle-ci répond aux besoins immédiats des personnes impliquées.

L'Énoncé des trois Conseils aborde aussi la question de l'inclusion des sujets dans les protocoles de recherches. Sur la base du principe de justice distributive, les membres de la société ne devraient jamais supporter plus que leur juste part du fardeau directement associé à leur participation à une recherche, pas plus qu'ils ne devraient être arbitrairement privés de ses éventuels avantages. Malheureusement, la recherche biomédicale a eu tendance à exclure les sujets très jeunes et très âgés, les sujets inaptes et les femmes en âge d'avoir des enfants souvent pour des raisons de responsabilité légale. Les chercheurs ont le devoir de ne faire aucune discrimination envers les groupes désavantagés, ce qui comprend les femmes, les gens de couleur ou d'ethnies différentes, les gens âgés, les enfants et les personnes inaptes.

Concernant les essais cliniques, l'énoncé introduit le principe d'équilibre clinique. Cela signifie qu'au début d'une étude doit exister un doute sur les mérites thérapeutiques comparés reliés à chaque groupe par- ticipant à l'essai de sorte que l'état de santé des sujets n'est pas affaibli par la participation à la recherche. C'est particulièrement pertinent quand on fait l'usage de placebos dans des groupes témoins, ce qui devrait être permis seulement s'il n'existe pas de traitement normalisé, si la thérapie régulière n'est pas meilleure que le placebo, si le traitement efficace n'est pas normalement offert aux patients ou si les patients ont transmis un refus libre et éclairé concernant le traitement normalisé d'une maladie bénigne pour laquelle les patients refusent généralement d'être traités.

Les sections qui présentent la recherche en génétique humaine illustrent les problèmes actuels et les dilemmes éthiques où l'anesthésiologiste peut être impliqué comme membre d'une équipe désireuse d'utiliser des tissus humains. Bien que la recherche soit passionnante, les connaissances récemment acquises au sujet des gènes et de leurs mutations ne sont pas associées à une compréhension suffisante de leurs implications. En conséquence, les questions relatives à la vie privée, à la confidentialité et à l'information génétique prédominent. L'énoncé affirme sans équivoque qu'il est immoral : d'utiliser du sperme ou des ovules obtenus à la suite de transactions commerciales, de créer des espèces hybrides au moyen de combinaisons de gamètes humains et animaux ou de créer des embryons humains uniquement à des fins de recherche. La plupart des recommandations de cette section sont basées sur la Commission royale sur les nouvelles techniques de reprodution. ${ }^{2}$ L'intrusion politique dans les principes éthiques est mise en évidence par la déclaration d'un ancien ministre de la Santé qui ne voulait pas approuver le financement fédéral pour des interventions qui impliqueraient la transplantation de tissus obtenus à la suite d'interruptions volontaires de grossesse même si la Commission royale avait recommandé que «les projets de recherche utilisant des tissus fotaux puissent être financés par le CRM.»

Les «Lignes de conduite sur l'éthique de la recherche clinique en anesthésie», préparées par le Comité de la bioéthique de la Société canadienne des anesthésiologistes (SCA) et publiées dans le présent numéro du Journal canadien d'anesthésie ${ }^{3}$ renforcent les propos de l'Énoncé des trois Conseils qui sont directement pertinents à l'anesthésie. En particulier, le comité reconnaît qu'il est difficile d'obtenir le consentement éclairé en recherche anesthésique, puisque le premier contact avec les patients peut n'avoir lieu qu'à l'hôpital, souvent le jour même de l'intervention chirurgicale. Le Comité établit clairement que le consentement préopératoire pour la recherche clinique en anesthésie peut être obtenu après l'admission à l'hôpital pourvu que certains critères soient satisfaits : les patients ne sont pas sous 
l'influence de médicaments sédatifs; les risques pour le patient ne sont pas différents de ceux de la pratique clinique habituelle (l'équilibre clinique); il y a suffisamment de temps pour présenter et expliquer le projet. Les Lignes de conduite de la SCA admettent les placebos en recherche anesthésique et donnent des conseils quant à leur usage; elles mettent en évidence les questions relatives à la vie privée et à la confidentialité, au potentiel de risques et d'avantages, aux populations vulnérables et à la déclaration de conflits d'intérêts possibles. Les responsabilités et les activités des chercheurs en anesthésie ont été identifiées en conjonction avec l'Énoncé de politique des trois Conseils. Les Lignes de conduite vont garantir plus facilement un comportement moral et éthique approprié en recherche clinique avec des humains au Canada.

Certaines questions éthiques concernant la recherche biomédicale n'ont pas été réglées. Lors de la réunion d'avril 1999 de l'Association médicale mondiale, certains changements à la Déclaration d'Helsinki ont été proposés. Entre autres, on recommandait de ne pas insister sur le consentement éclairé écrit quand la recherche ne comportait que des risques faibles; qu'il est souhaitable plutôt qu'obligatoire que le consentement soit obtenu par un médecin impartial; que les groupes témoins reçoivent les soins normalisés dans leur région plutôt que la meilleure thérapie reconnue; que les placebos puissent être justifiés par un protocole valable aux plans scientifique et éthique; que l'interdiction de publier des recherches peu éthiques soit moins stricte. Quelques propositions de révision font suite à des études, dans les pays en voie de développement sur la zidovudine chez des femmes enceintes dans le but de prévenir la transmission du VIH à leur progéniture, dans lesquelles la thérapie placebo a été utilisée chez les sujets témoins plutôt que la «meilleure thérapie reconnue». Le propos a fait l'objet de débats animés ${ }^{4,5}$ et montre le besoin de poursuivre la discussion sur cette question controversée. Néanmoins, les recommandations qui ont été faites par des générations de chercheurs médicaux nous assurent qu'en recherche biomédicale le principe fondamental du respect de la dignité humaine est maintenu et que les atrocités passées ne se reproduiront jamais plus. L'Énoncé de politique des trois Conseils et les Lignes directrices de la SCA ont notamment établi les règles pour les anesthésiologistes.

\section{References}

1 Tri-Council Policy Statement. Ethical conduct for research involving humans. 1999.

2 Report of the Royal commission on New Reproductive Technologies, Proceed with Care, Ottawa, 1993.
3 Committee on Bioethics Canadian Anesthesiologists' Society. Guidelines on the ethics of clinical research in anesthesia. Can J Anesth 2000; 47: 87-90.

4 Brennan TA. Proposed revision to the declaration of Helsinki - will they weaken the ethical principles underlying human research? N Engl J Med 1999; 341: 527-31.

5 Levine RJ. The need to revise the declaration of Helsinki. N Engl J Med 1999; 341: 531-4. 